\title{
Problem-based Learning Strategies for Teaching Military Social Work Practice Behaviors: Review and Evaluation
}

\author{
James D. Whitworth \\ Joseph R. Herzog \\ Diane L. Scott
}

\begin{abstract}
This article outlines and evaluates a military social work course as it has been taught by three social work faculty members at two universities in the southeastern US. The authors highlight why these courses are needed within social work undergraduate and graduate programs. They report how CSWE-identified military practice behaviors are addressed within the course. They also describe how practice-based learning approaches appear to be ideally suited for teaching military social work curricula. Data on student perceptions of military social work courses and the application of problembased learning are presented along with an assessment of knowledge gains and ability to practice military social work. Findings reflect that social worker students find these courses helpful and that they believe that problem-based courses in this subject help prepare them for initial work with this population. They also highlight the need for an extensively updated military social work textbook addressing major changes within the military and social work over the last decade.
\end{abstract}

Keywords: Military social work, problem-based learning, practice behaviors, social work education, Council on Social Work Education (CSWE)

\section{INTRODUCTION}

Military and civilian social workers play a vital role in sustaining and supporting military members, veterans, and their families. Their role has grown and adapted during the last decade with the recent wars in Afghanistan and Iraq. Social workers have historically taken the lead in programs to prevent and respond to substance abuse, and family maltreatment along with providing mental health services and medical social work. They are now key players in developing and providing individual, family, and community responses to help those impacted by combat-related trauma, military deployments, and mild traumatic brain injuries.

The developing role of social workers within the military has been largely fueled by a significant increase in deployments and the expanded use of Reserve and National Guard members (Adams, Durand, Burrell, Teitelbaum, Pehrson, \& Hawkins, 2005; Knox \& Price, 1999). The number and frequency of deployments have led to unparalleled strains on the military, their families, communities, and caregivers. Many military members have been deployed for six to 18 months with the period of time between deployments getting shorter (Hosek, Kavanagh, \& Miller, 2006). Many service members have been regularly exposed to nontraditional hostile combat conditions where they observed fellow military

James Whitworth, Ph.D., and Joseph Herzog, Ph.D., are assistant professors and Diane Scott, Ph.D., is an associate professor at the School of Justice Studies and Social Work, University of West Florida, Pensacola, Florida. 
members being injured or killed (Hoge, Castro, Messer, McGurk, Cotting, \& Koffman, 2004).

Military social workers have been described by some as mental health "first responders" to military members since they often deploy to combat zones (Savitsky, Illingworth, \& DuLaney, 2009). Given the growing need for social workers, and the demands on active duty providers, social work services are increasingly being provided by civilians (Savitsky, et al., 2009). There is also an increased recognition of the military as a separate culture with unique and specific norms, challenges, strengths, and needs. These factors, among others, highlight the need to provide social work students with specialized training to prepare them for working with this population.

Leadership is now emerging within social work education to assure that social work students are appropriately trained to respond to the needs of today's military, veterans, and their family members. The Council on Social Work Education (CSWE) stated "specialized education to prepare social workers to aid this population (military) is clearly indicated” (CSWE, 2010, p. 1). CSWE recently delineated practice behaviors for advanced practice in military social work for each of their 10 core competencies specified by the 2008 Educational Policy and Accreditation Standards (CSWE, 2010).

Although some educators have been disseminating and teaching military-focused social work publications and courses for many years, specific training programs and curriculum focused on preparing social worker students to work within the military has more broadly developed within the last five years. Courses to teach undergraduate and graduate students about military social work are now being taught in a minimum of 30 CSWE-accredited social work programs within the U.S. (CSWE, 2010). Students in these courses are learning essential information about working with military members, veterans, and their families along with being exposed to new interventions to help these groups. Social work students appear to be generally quite receptive to taking military social work courses especially at those universities in close proximity to military installations. Many of these courses intentionally address some of the inherent ethical issues and conflicts that arise for helping professionals working within a military context.

Only minimal research into the content and outcomes of military social work courses exists. The authors found one qualitative investigation that interviewed 24 graduatetrained social workers who had deployed to combat areas (Simmons \& DeCoster, 2007). The social workers participating in that study had all completed CSWE-accredited graduate social work programs, and had not completed a military social work class prior to their deployments. They primarily described their social work education as helpful in preparing them to work in combat areas.

The present review and investigation outlines a military social work course using Problem-based Learning (PBL) approaches. The course was developed and taught by three social work faculty members involving nearly 100 graduate and undergraduate students at two universities in the southeastern U.S. The authors describe how CSWEidentified military practice behaviors were taught within the course. Specific examples of PBL curricula are provided. Findings from an evaluative survey of the course are also detailed. 


\section{Military Social Work}

Military social work is a broad term encompassing social services provided to active duty, National Guard, or Reserve military members, veterans, their family members, and the communities in which they live (CSWE, 2010). It includes all social workers who provide these services such as uniformed and civilian social workers working within any of the branches of the Department of Defense (DoD), the Veterans Administration (VA), private and public social service agencies, and practitioners who treat or work for any of the above individuals, groups, or organizations. Military social work "involves direct practice; policy and administrative activities; and advocacy including providing prevention, treatment, and rehabilitative services to service members, veterans, their families, and their communities” (CSWE, 2010, p. 2). Daley (2003) listed six functions (See Table 1) as "international core requirements for military social work" (pp. 438-439). These six functions succinctly capture the primary focus and purpose of military and civilian social workers serving within the military services.

Table 1. International Core Requirements for Military Social Work (Daley, 2003, pp. 438-439)

\section{Function}

1. Enhance military members’ capability to conduct and recover from warfare

2. Develop or consult on military policies and procedures which minimize psychosocial damage while maximizing military member and family wellness within military structural boundaries

3. Build and/or implement programs which reduce the likelihood of damage from psychosocial problems such as family violence, substance abuse, mental illness, or maladjustment to serious medical illness

\section{Offer intra-military perspectives and interventions to improve service functioning}

5. Ensure the highest quality of professionalism in delivery of military social work services

6. Disseminate cumulative historically effective technologies

\section{Practice Behaviors for Advanced Practice in Military Social Work}

The Council on Social Work Education (CSWE) recently delineated practice behaviors for advanced practice in military social work for each of their 10 core competencies specified by the 2008 Educational Policy and Accreditation Standards (CSWE, 2010). Although the course described in the present study was taught both before and after these practice behaviors were created, the class expressly addressed them throughout the time that it was offered. In particular, the courses address practice 
behaviors related to ethical principles, application of critical thinking, research-informed practice, human behavior in the social environment, contexts that shape practice, and engagement, assessment, intervention, and evaluation at multiple levels. Table 3 identifies where these practice behaviors were taught within the course.

\section{Problem-based Learning Approaches}

PBL, also called inquiry-based learning, is a teaching method that has been used across multiple disciplines for nearly four decades within the US and many other countries (Savery, 2006). Originally and continuously used within medical education, PBL employs "real-world" problems and scenarios as a context for students to practice problem-solving skills while increasing their subject matter knowledge (Lam, 2009). Instructors who use this approach seek to provide an active-learning environment where students are challenged to use course material to assess and respond to realistic problems. PBL approaches were created out of a belief that more "traditional", primarily didactic, lecture or instructional methods rarely give students a working content application context (Savery, 2006). Barrows (1996) described PBL as having the following core elements:

- $\quad$ Learning is student centered

- Learning occurs in small groups

- Teachers are facilitators or guides

- $\quad$ Problems are the organizing focus and stimulus for learning

- $\quad$ Problems are the vehicle for the development of clinical problem-solving skills

- New information is acquired through self-directed learning (p.5)

Research comparing the effectiveness of PBL to more conventional approaches for teaching multiple disciplines, is somewhat mixed and inconclusive (Kam Pun Wong \& Lam, 2007). Most studies to date, especially those conducted in non-medical fields, had limited or no controls. However, a meta-analysis of 20 years of investigations into courses taught with a PBL approach concluded that students who were taught with these methods demonstrated equal knowledge acquisition when compared to those who learned with more traditional methods and they showed evidence of superior clinical problemsolving skills (Albanese \& Mitchell, 1993). A second meta-analysis of 43 studies concluded that PBL consistently helped students on skills-related outcomes (Dochy, Segers, Van den Bossche, \& Gijbels, 2003). Students almost universally reported high levels of satisfaction with PBL courses, and they repeatedly stated that they generally prefer this method over traditional approaches (Savery, 2006).

The use of PBL instructional approaches within social work education at the Bachelor of Social Work (BSW) and Master of Social Work (MSW) levels has consistently increased over the last twenty years. PBL has been used in schools of social work within the US, the United Kingdom, Australia, and Hong Kong (Lam, 2009). Some of these schools have employed PBL approaches across their entire curriculum (Kam Pun Wong \& Lam, 2007). Schools of Social Work adopted PBL instructional methods to help students start to "think like social work professionals" and as a means of increasing the 
transfer of classroom learning to the field (Williamson, Chang, Fellows, \& Decker, 2007).

Rigorous evaluation into the impacts of PBL approaches on social work student outcomes is limited. Most investigations to date had difficulty employing student control groups. Two separate mixed-methods (quantitative and qualitative) single-cohort pre-and post-test studies of social work students taught with PBL methods were conducted at the University of Hong Kong (Kam Pun Wong \& Lam, 2007; Lam, 2009). This university broadly adopted PBL instructional concepts across their social work program. These researchers found evidence that PBL courses taught at the BSW level stimulated student "growth in employing multiple sources of learning, directed their own learning goals and activities, and teamwork collaboration" (Lam, 2009, p. 1499). They also found that PBLinstructed students reported statistically significant increases in their social work knowledge, skills, and values compared to when they began the academic year. The generalizability of these findings is clearly limited by the lack of controls. Such student gains would arguably be anticipated with active participation in most CSWE accredited programs irrespective of teaching approach.

Beveridge and Archer (2006) compared social work student's perceptions of a social work course taught using PBL approaches to their perceptions of a required psychology course that employed traditional didactic teaching methods. All 70 study participants took both classes. Students reported a stronger mastery of the achievement goals of the class, utilizing effective study strategies, and had a more positive perception of studying in the PBL-based social work course.

A smaller sub-sample of students in the Beveridge and Archer (2006) study reported in interviews that they liked the social work course's "high degree of challenge, authentic tasks, self-directed learning, autonomy and choice, collaboration with peers, developing of cognitive strategies, cognitive engagement, high level of relevance of material, and developing a personal knowledge base” (p. 13). Other studies found similar social work student perceptions of PBL-focused courses to include a belief that these courses make them feel more confident to practice social work skills and better prepared for practice (Williamson, et al., 2007). Field supervisors and employers of social workers also reported that students who take multiple courses using PBL techniques appear more confident than their social work peers (Lam, 2009). Although the majority of students noted that they enjoy learning with PBL methods, some in at least two studies also stated that they struggled with a perceived the lack of structure in group activities, negative group dynamics, having to trust other students to complete tasks, and inadequate collaboration skills in social work courses taught using a PBL approach (Beveridge \& Archer, 2006; Hartsell \& Parker, 2008).

\section{METHOD}

\section{Course Description, Objectives, Curriculum}

Six introductory military social work courses were taught by three instructors over two years at two universities in southeastern US. All six courses were taught from a basis 
core syllabus, using the same textbook (Daley, 1999) with each faculty adding supplemental material as they saw fit. Table 2 details the course schedule along with required readings. Four of the courses were provided online and the other two were taught using a blended (on-line and in-person) format. Five of these courses were provided at the MSW level and one was for BSW students. One of the universities where five of the courses were taught was in a community with multiple military installations and the other university has an extended history of providing courses for military members, veterans, and their families. The course was offered at both schools as an advanced clinical practice elective for MSW students or as a general elective for BSW students.

Table 2. Course Schedule and Required Readings

\begin{tabular}{|c|c|c|}
\hline Week & Topic & Required Reading \\
\hline 1 & Course Introductions - Overview & \\
\hline 2 & History of Military Social Work & $\begin{array}{l}\text { Daley(1999) - Chapters 1,2,3 } \\
\text { Military Facts for Non-Military Social } \\
\text { Workers (Kadis \& Walls, 2005) }\end{array}$ \\
\hline 3 & $\begin{array}{l}\text { Legal and Ethical Dilemmas in Military } \\
\text { Social Work }\end{array}$ & Daley (1999) - Chapter 11 \\
\hline 4 & Family Advocacy in the Military Services & Daley (1999) - Chapter 4 \\
\hline 5 & $\begin{array}{l}\text { Medical Social Work and the Impact of } \\
\text { Tricare in the U. S. Armed Forces }\end{array}$ & Daley (1999) - Chapters 5,7 \\
\hline 6 & $\begin{array}{l}\text { Military Social Work Practice in Substance } \\
\text { Abuse Programs }\end{array}$ & Daley (1999) - Chapter 6 \\
\hline $7 / 8$ & $\begin{array}{l}\text { Military Social Work Practice in Mental } \\
\text { Health Programs }\end{array}$ & Daley (1999) - Chapter 8 \\
\hline 9 & $\begin{array}{l}\text { Combat-Related Post Traumatic Stress } \\
\text { Disorder (PTSD) and Mild Traumatic Brain } \\
\text { Injury (mTBI) }\end{array}$ & $\begin{array}{l}\text { Cigrang et al. (2005) } \\
\text { Hoge et al. (2004) } \\
\text { Litz (2007) }\end{array}$ \\
\hline 10 & $\begin{array}{l}\text { The Impact of Combat-Related PTSD and } \\
\text { mTBI on families }\end{array}$ & $\begin{array}{l}\text { Chapin (2009), Adams et al. (2005) } \\
\text { McFarlane (2009), Herzog \& Everson } \\
\text { (2010) }\end{array}$ \\
\hline $11 / 12$ & $\begin{array}{l}\text { Suicide Assessment and Response within } \\
\text { the Military }\end{array}$ & $\begin{array}{l}\text { Air Force Guide to Managing Suicidal } \\
\text { Behavior (2002), Knox et al. (2010) }\end{array}$ \\
\hline $13 / 14$ & $\begin{array}{l}\text { Building Community Capacity in Military } \\
\text { Communities: The Integrated Delivery } \\
\text { Service Approach }\end{array}$ & Huebner et al. (2009) \\
\hline 15 & $\begin{array}{l}\text { Service Member and Family Wellness } \\
\text { across the Lifespan }\end{array}$ & Daley (1999) - Chapters 16,17,18 \\
\hline
\end{tabular}


All three instructors had a strong interest and involvement in military social work prior to teaching the course. One instructor was an active-duty Air Force social worker; another had worked as a civilian social worker within the military and is married to a retired Soldier, while the third instructor had been a private practitioner near military installations for over 15 years with a heavy military case load.

The course description is provided below:

This course provides a comprehensive and in-depth examination of the practice of military social work. SWK \#\#\# outlines the historical context of specific practice of social work within the branches of the U.S. military. The course will enable students to understand some of the unique challenges and needs of military members and their families. They will learn specific community and clinical practices to help military members and their families. The course also examines the unique culture of the military community along with specific ethical dilemmas faced by active duty and civilian social workers practicing in a military setting.

The course objectives are provided in Table 3 along with the CSWE-identified Military Practice Behaviors that they addressed. Each CSWE Education Policy (EP) or competency is also specified within the table. The first half of the course largely focused on topics that can be described as fundamental military social work curricula, which generally mirrored many of the chapters within the Daley (1999) textbook. They included: History of Military Social Work, Legal and Ethical Dilemmas in Military Social Work, Family Advocacy Programs, Substance Abuse Programs, Medical Social Work, Tricare, Mental Health Programs, and Military Member and Family Wellness across the lifespan. The second half of the class addressed topics that have arisen as essential for military social workers over the last decade such as Combat-Related Post Traumatic Stress Disorder (PTSD), Mild Traumatic Brain Injury (mTBI), Impact of PTSD and mTBI on Families, Suicide Assessment and Response, and Building Community Capacity within Military Communities.

\section{Incorporation of Military Practice Behaviors}

The course centers on many of the key elements highlighted within the CSWEidentified practice behaviors. Table 3 reviews each of the course objectives and links them to the specific practice behavior that was addressed. Each CSWE Education Policy (EP) or competency is also noted within the table. Specific emphasis was placed in the course on students learning the following topics within the military population: cultural competency, historical context, systems perspective concepts, bio/psycho/social variables, ethical dilemmas, and evidence-based practice.

The social work profession has consistently stressed the importance of cultural competency. Although there are numerous and somewhat varying ways to define cultural competency, Cross, Bazron, Dennis, and Isaacs (1989) appropriately described it "as a set of congruent behaviors, attitudes, and policies that come together in a system or agency, or among professionals, that enable the system, agency, or those professionals to work effectively in cross-cultural situations” (p. 1). Given that the US military has many 
Table 3. Course Objectives, CSWE-identified Military Practice Behaviors, and Education Policies (EPs) Addressed within the Course

\begin{tabular}{l} 
Course Objective \\
\hline Apply knowledge of the \\
variables within the military \\
structure and environment that \\
affect social work practice \\
Describe the historical context of \\
social work practice within the \\
armed services
\end{tabular}

armed services

Use systems perspective concepts and framework to assess military client problems and develop interventions

Identify, understand, and describe bio/psycho/social variables that impact human behavior in the military

Describe the impact of changing societal structures on human relationships in the military

Identify and respond to ethical dilemmas involved in practicing social work with active duty military members

Know and assess evidence-based practices for treating mental conditions common among military members and their families

\section{CSWE Military Practice Behavior \& EP}

Demonstrate a professional demeanor that reflects awareness of and respect for military and veteran cultures (EP 2.1.1)

Recognize boundary and integration issues between military and veteran cultures and social work values and ethics (EP 2.1.1)

Assess service systems' history, trends, and innovations in social work practice with service members, veterans, their families, and/or their communities (EP 2.1.9)

Apply knowledge of practice within the military context to the development of evaluations, prevention plans, and treatment strategies (EP 2.1.9)

Assess service systems' history, trends, and innovations in social work practice with service members, veterans, their families, and/or their communities (EP 2.1.9)

Recognize and assess social support systems and socioeconomic resources specific to service members, veterans, their families, and their communities (EP 2.1.6)Recognize the impact of military transitions and stressful life events throughout the family's life course (EP 2.1.6)

Identify issues related to losses, stressors, changes, and transitions over their life cycle in designing interventions (EP 2.1.6)

Demonstrate the ability to critically appraise the impact of the social environment on the overall well-being of service members, veterans, their families, and their communities (EP 2.1.6)

Identify and analyze conflictual responses and potential consequences to conflicts between basic human rights and military life and duty experience (EP 2.1.5)

Employ strategies of ethical reasoning in an environment that may have policy and value conflicts with social work service delivery, personal values, and professional ethics (EP 2.1.2)

Identify the military culture's emphasis on mission readiness, support of service, honor, and cohesion and how these influence social work service delivery at the micro, mezzo, and macro levels (EP 2.1.2)

Locate, evaluate, and analyze current research literature related to military social work (EP 2.1.6)

Evaluate research to practice with service members, veterans, families, and their communities (EP 2.1.6)

Analyze models of assessment, prevention, intervention, and evaluation within the context of military social work (EP 2.1.6)

Apply different literature and evidence-informed and evidence-based practices in the provision of services across the DoD/VA continuum of care and services (EP 2.1.6) 
aspects of a separate culture or subculture, it is vital that social workers who work within this population understand as much as they can about how the military functions. Students within the military social work course described here learned information about each of the military services, their unique behaviors, attitudes, and policies.

Students in the course also learned about how social workers have been working within the US military for nearly a century, and that they have helping veterans and their families for longer than that. The course provides information to understand the rich history of military social workers to include the early role of the Red Cross, accomplishments and challenges faced by pioneering military social workers, and how social work roles adapted over time with many changes within the US military and the VA systems. Students are also taught about how social workers led in the development and provision of substance abuse and family maltreatment programs across the military services.

A significant portion of the course is dedicated to understanding the unique bio/psycho/social needs of military members, veterans, and their families. Students learn about the impacts of frequent transitions, losses, and deployments among this population along with programs and interventions to lessen the impacts of these challenges. They also learn about innovative ways to foster community capacity to respond to needs and problems within military communities.

Ethical conflicts appear to be inherent for social workers who practice in or with a military population. These conflicts often result from the high priority placed on accomplishing the military mission while concurrently assuring that members, veterans and their families are acknowledged as independent humans with ongoing bio/psycho/social needs. Students in the course learn about these conflicts along ways to avoid them when possible, and they are instructed on available means to attempt to resolve them. They similarly learn about conflicts arising from the differences between civilian legal systems and those involving the military Uniformed Code of Military Justice (UCMJ).

Extensive emphasis in the course is placed on learning and "practicing" evidencebased treatments for conditions common among military members, veterans, and their families. These conditions include PTSD, substance-related problems, mTBI, and secondary trauma response. Students are required to review and critically analyze the research which supports emerging military-specific treatments for these conditions.

\section{Use of Problem-based Learning Approaches}

The course instructors employed PBL approaches by challenging students to apply each week's lessons and material to a realistic military social work clinical or community scenario. After reviewing each scenario, students would individually formulate their analysis of the case or situation. This analysis included the student's assessment and delineation of the military client, family, or community needs and challenges, and specific strengths. Students were also required to explicitly detail how they would intervene as a social worker within the scenario. In the online courses, students would 
then post their analysis of the scenario to their small (usually 5-7 students) discussion groups. They would then provide detailed feedback assessing at least two other group members scenario reviews although they often commented on more than two reviews. The instructors provided guiding feedback and comments for each of the group discussions. They however, left the leadership of each discussion up to the students. Students were graded individually on their ability to appropriately assess the scenario and develop a viable intervention plan utilizing primarily material addressed during the course. For the blended courses, the scenario application exercises were done as formal class presentations with discussions following each.

Case scenarios represented a wide-range of clinical and community challenges and situations common within military and veteran populations. Each scenario highlighted key aspects of the course material. Some of the scenarios included a young military couple dealing with post-deployment issues, family members caring for a severely injured soldier, substance abuse by a junior military member, ethical conflicts for a civilian social worker providing services on a military installation, a community responding to several military member suicides, and a member who wants to leave the service early, along with several other relevant military scenarios. Case scenarios included veterans, family members, and members from all military branches and from locations throughout the world. Students were advised that all scenarios were not actual cases or situations, but that they were representative of clinical and community scenarios that military social workers regularly address.

The following sample scenario used by one of the instructors challenged students to respond to a family maltreatment situation:

Petty Officer Second Class (PO2) Michael Johnson is a 28 year old Sailor currently stationed at Eglin Air Force Base in Florida where he is attending Explosive Ordinance Disposal (EOD) School. He just arrived at the school last week to begin a 7-9 month program to train him as an EOD Technician. He has been in the Navy for seven years. He has worked as an Electronic Technician for his entire career up until now which required him to be at sea for long periods (5-8 months at a time). He liked the work that he did as an Electronic Technician. However, he is very motivated to succeed as an EOD Technician because of the complex type of work he will be doing and the increased status and pay that will come from this job. P02 is married to Amanda and they have two children ages four and six. Amanda and the children are still living at his previous base (San Diego Naval Base) in California.

PO2 Johnson was brought to your office at the Eglin AFB Family Advocacy Program (FAP) office by his training supervisor, Senior Chief Petty Officer (SCPO) Barker. You are employed as a Family Advocacy Treatment Manager (FATM), which is a civilian social work position within FAP. You conduct assessments of child and spouse abuse allegations and provide treatment interventions for military members and their families who have been involved in substantiated maltreatment. SCPO Barker requests to meet with you while PO2 Johnson is completing some initial paper work. He states that he brought PO2 
Johnson to your office at the request of the commander of the EOD School. The commander had been called by PO2 Johnson's previous supervisor in San Diego who states that Amanda is alleging that Michael physically abused her three days before leaving to come to his EOD program. She is also alleging that he left her with only $\$ 100$ cash and no access to any other funds to pay their bills. Before meeting with Michael you call the FAP staff at the San Diego Naval Base. They tell you that Amanda has called them also to report the abuse. They state that they evaluated and substantiated a mutual spouse abuse case with Michael and Amanda about 14 months ago. Michael attended 5 individual counseling sessions with a FAP counselor and that he completed a six-month men's domestic violence treatment course. Amanda met once with a Victim Advocate, but she declined to participate in FAP treatment or other services. The San Diego Base FAP staff hasn't met with Amanda to assess the current situation/allegations, but they have an appointment scheduled with her tomorrow morning.

You meet with PO2 Johnson for 75 minutes to assess the allegations and to evaluate his emotional status. He is initially very quiet in the interview and is clearly quite angry about the allegations. He is concerned that he will be kicked out of the EOD program. Michael denies that he harmed Amanda, but does admit that they had a significant argument three days before her left for school. He admits to pushing Amanda aside to get out of their apartment because "she was blocking the door and yelling at me in front of the kids." He tells you he thinks Amanda is "psycho" and that she needs mental health care. When you ask him for details about this statement, he states he is not able to describe any specific severe mental illness behaviors of Amanda, but that he thinks that Amanda wants to ruin his Navy career. He believes that she may be having an "internet relationship" with a guy she knew back in high school. Michael has not been sleeping well the last two nights. He states that this is because he is worried about the impact that this situation will have on his training and his career. He admits to feeling depressed, anxious, and angry. Michael denies any suicidal or homicidal thoughts, plan or intent. He also denies that he abuses alcohol or that others have been concerned about his alcohol usage.

\section{Survey}

All students who had taken the course within the two prior years were asked to complete a survey regarding the class (see Attachment). Administration of the survey was approved by both universities' Institutional Review Boards. The brief survey was conducted through Survey Monkey. Participating students responded to survey items assessing their knowledge of information reflecting Military Social Work Practice Behaviors, student attitudes regarding doing social work with military members and their families, student's anticipated social work practice with military members/families, or veterans and student perceptions of use of PBL concepts within the course. There were also several "open-ended" questions requesting students to provide feedback on their overall perceptions of the course. 


\section{RESULTS}

\section{Sample}

The final sample included 19 students. Of the 110 surveys sent to students, 30 surveys were undeliverable due to incorrect email addresses. The final response rate was $23 \%$. A small number (26\%) of the respondents were either current military members or veterans while the majority (63\%) reported being married to either a current military member or veteran. Thirteen respondents (68\%) reported previous work experience with military members, veterans, or their family members. Almost a third (32\%) of the students reported very little to no knowledge of military populations prior to taking the military social work course while a greater number (52\%) reported a good to moderate knowledge and a smaller number (16\%) reported extensive knowledge. The majority of students (79\%) are either working or plan to work with military populations.

\section{Military Population Beliefs}

All of the students (100\%) believed that concerns about confidentiality and the impact of receiving care on the career of the service member to be potential barriers for seeking social service assistance. Over half (53\%) of the students believe limited coping skills to put young military families at risk while a smaller number believed the cause to be either strained finances (21\%) or young age (16\%) and one student (5\%) none of the above were risk factors. Separation from natural resources was selected by a majority of students (84\%) as a unique demand and risk for military members and their families. The majority of students (72\%) correctly indentified Family Advocacy Program, Substance Abuse Programs, Medical Programs, or Mental Health Programs as agencies whose primary focus is "Mission readiness."

\section{Problem-based Learning}

The majority of students (79\%) remembered the case scenarios that were presented in class. Likewise a vast majority of students (93\%) of the students who answered this question believed the case scenarios to be helpful to very helpful in helping them to understand military populations (26\% of respondents left this item blank).

\section{Military Population Task Abilities}

Students rated their abilities to perform specific tasks with military populations on a scale from 0 (cannot do at all) to 100 (certain can do) with a midpoint of 50 (moderately certain can do) (See Table 4). Of the 19 students who responded to the survey, 17 completed this section. The mean for specific task performances ranged from a low of 82.3 for "Review all aspects of the client's case and history to determine benefit eligibility" to a high of 92.3 for "Provide information about substance abuse to military members or veterans." One student rated them self less than moderately certain they could perform specific tasks with that student rating a 20 on "Review all aspects of the client's case and history to determine benefit eligibility" and a 30 on "Establish rapport with clients from different cultural backgrounds and experiences” while another student 
rated a 30 on "Network with agencies to coordinate services for military members or veterans" and a 40 on "Define military member or veterans' problems in specific terms." The remaining 15 students were at least moderately certain (50) that they could perform all of the specific tasks inquired about with military populations.

\section{Responses to Open-ended Items}

Students responded to open-ended questions regarding their experience and the settings of their work with military populations, their goals in taking the course, information they recalled from the case scenario application exercises in the course, and their overall perceptions of the course. Not surprisingly, given the close proximity of one of the universities to military installations and the close association of the other with the military, seven of the thirteen students $(53.8 \%$; $n=19)$ who indicated they had prior experience with military populations were veterans, active-duty or family members of veterans who cited that experience. The same number of students $(7 ; 53.8 \%)$ indicated they had experience with military populations during their social work internships, previous employment or volunteer experiences.

Table 4. Descriptive Statistics for Task Abilities Items

\begin{tabular}{|c|c|c|c|}
\hline Item & $\mathbf{N}$ & Mean & $S D$ \\
\hline $\begin{array}{l}\text { Review all aspects of the client's case and history to determine benefit } \\
\text { eligibility. }\end{array}$ & 17 & 82.35 & 20.77 \\
\hline $\begin{array}{l}\text { Identify barriers to obtaining services and develop plans for } \\
\text { overcoming barriers. }\end{array}$ & 17 & 84.70 & 16.24 \\
\hline $\begin{array}{l}\text { Establish rapport with clients from different cultural backgrounds and } \\
\text { experiences. }\end{array}$ & 17 & 87.64 & 20.77 \\
\hline $\begin{array}{l}\text { Understand the impact of substance abuse on military members or } \\
\text { veterans }\end{array}$ & 17 & 90.58 & 10.28 \\
\hline $\begin{array}{l}\text { Critically evaluate substance abuse issues with a military member or } \\
\text { veteran. }\end{array}$ & 17 & 91.17 & 9.27 \\
\hline $\begin{array}{l}\text { Provide information about substance abuse to military members or } \\
\text { veterans. }\end{array}$ & 17 & 92.35 & 12.51 \\
\hline $\begin{array}{l}\text { Work with various systems to obtain services for military members or } \\
\text { veterans. }\end{array}$ & 17 & 90.58 & 8.99 \\
\hline Advocate on behalf of military member or veteran & 17 & 90.58 & 13.44 \\
\hline $\begin{array}{l}\text { Network with agencies to coordinate services for military members or } \\
\text { veterans. }\end{array}$ & 17 & 86.47 & 16.93 \\
\hline Define military member or veterans' problems in specific terms. & 17 & 83.53 & 15.78 \\
\hline
\end{tabular}

Students had varied goals and desired outcomes from the military social work course. Nine students (50\%; $n=19$; 1 blank) reported that they had taken the course to prepare for their internship or future employment within agencies serving military populations. Students said, "my goals for taking the social work class were directly linked to my 
desire to practice SW here in Pensacola, a military town. I was also hoping to use the information learned during possible internship with the VA." Others reported wanting to be "able to work with military families as a family advocate" and "moving from base to base supporting my husband's career and I would like to be able to continue my career as a social worker on military bases.” The majority of students (14; 73.7\%) most commonly indicated an overall desire to become more familiar with the military community. They expressed goals to learn about the "history, roles, and impact social work has for the military," "the structure and background of the military," "the dynamics of military service," and "the issues military families face during their life as a member of the armed services," and to "gain more knowledge about the military community and how social work is integrated into that community."

Consistent with research on student learning using PBL (Lam, 2009), students were able to identify the scenario exercise and specific details about the interventions in 13 responses (68.4\%; 6 blank; $n=19)$. This is noteworthy because the six courses were taught from 2008 to 2011. The overall feedback question yielded more support for using the case scenarios. For example, "the course was good because it left room for people to do more research on the military" and "the exceptional design [which] focused on a detailed inside view of the military soldier and families. If you thought you knew what a military service member or families of service members experience during their tours of duty, before taking this course, you would be surprised to find out how much more there really is to know." And, a student who was in the blended version of the course said "it was great to discuss real life scenarios and I enjoyed the reading material and presentations". Finally, as found by Barrows (1996) several students made comments similar to the following made by one student "the information learned was broad spectrumed, but specific to caseloads. It was helpful in that the scenarios brought a certain realness to the subject at hand. Having to assess each case and interpret what was needed helped to define what the social work job was and how it should be done." One student suggested adding to the curriculum "an Advanced SW in the Military class ... to get even more indepth information and experience."

\section{DISCUSSION AND IMPLICATIONS}

This article describes one method for teaching military social work classes to BSW and MSW students. The evaluation components of the present study were intended to explore and identify the primary benefits that students perceive from taking a PBLcentered introductory military social work course along with gauging some of their knowledge gains. Generalizability of the findings is significantly limited by a small and convenient sample size, lack of any control group, and moderately low response rate. This rate was largely impacted by the fact that many of the students had already graduated from their social work programs thereby making it difficult for the researchers to contact these individuals. The post-test only design also significantly limits drawing any conclusions based on the results. Use of a pre-test, post-test design would strengthen any assessment regarding the impact of the course content.

Despite the limitations noted above, this study provides some exploratory and qualitative evidence to suggest that PBL approaches are helpful for teaching military 
social work courses. Students who responded to the survey almost universally reported that they believed the course was highly helpful in preparing them for working with military members, veterans, and their families. Many students entered this course with little or no knowledge of military populations, while many others had no work experience with military populations. Some of the students had limited life experiences with military populations and few students had any direct military experience. After taking this course, the vast majority of students reported being at least moderately certain of their ability to perform specific tasks with military populations. Most of these students could recall the PBL approaches and the scenarios. A great majority of students perceived this technique to have been helpful in understanding military populations.

Future investigations of initial military social work courses would benefit from prospective and longitudinal research methods to improve response rates, gather meaningful current and more long-term effects of the course, and PBL approached to teach social work material. The use of control groups or classes would allow for better comparison of this course to traditional or other methods.

The high level of military experience among the faculty who taught the course described in this study may be an invaluable pre-requisite for creating such a course and addressing the detailed military, veteran or family case scenarios. The present findings also suggest that this course may be better suited to in-person or interactive teaching methods.

There is a clear need for further evaluation and development of these initial military social work courses along with creating more advanced military social work courses to address military-related topics. Future courses might address such issues as helping military members and their families with deployments, assessment and treatment of PTSD and mTBI, interventions with veterans, and bereavement/loss among the military and veteran populations. They could make up the central curriculum components of a military social work concentration or certificate program. Given that the primary textbook employed in many military social work courses (Daley, 1999) is over 12 years old, there is an evident need to either substantially update that textbook to incorporate social method in response to emerging military needs and current research findings or create a comprehensive new text book to address this new material.

\section{CONCLUSION}

The military social work course described in this article appears to be meeting a need to train practitioners who are informed and sensitive to the specialized and growing needs among military members, veterans, and their family members. This course, along with the increasing number of similar courses at universities throughout the US, responds to a critical need to appropriately train social workers before they start to work with this population. Participating social work students report that these courses helped prepare them for initial military-related social work and improved their perceived ability for working with this population even though many had limited direct prior experience with the military. Many students who thought they knew military populations quite well 
because of their personal experiences before taking the course commented about the knowledge that they gained after participating in the class.

The course detailed in this review was able to specifically address the essential military practice behaviors outlined by CSWE. It is also evident that Problem-based Learning approaches appear to be well-suited for teaching initial military social work courses given their focus on use of realistic problems which challenges students to integrate and apply curricula to a military or veteran client, family, or community problem. Social work educators should be able to apply the information detailed in this review along with the PBL approaches to initiate teaching their own military social work courses.

\section{References}

Air Force Medical Operations Agency. (2002). Air Force guide to managing suicidal behaviors: Strategies, resources, and tools. Retrieved from http://afspp.afms.mil/idc/groups/public/documents/afms/ctb_016017.pdf

Adams G. A., Durand, D. B., Burrell, L., Teitelbaum, J. M., Pehrson, K. L., \& Hawkins, J. P. (2005). Direct and indirect effects of operations tempo on outcomes for soldiers and spouses. Military Psychology, 17, 229-249.

Albanese, M. A., \& Mitchell, S. (1993). Problem-based learning: A review of the literature on its outcomes and implementation issues. Academic Medicine, 68(1), 5281.

Barrows, H. S. (1996). Problem-based learning in medicine and beyond: A brief overview. New Directions for Teaching and Learning, 68(3), 3-12.

Beveridge, A., \& Archer, J. (2006, November). Motivational implications of problembased learning for the preparation of social workers. Paper presented at the annual meeting of the Australian Association for Research in Education, Adelaide.

Chapin, M. (2009). Deployment and families: Hero stories and horror stories. Smith College Studies in Social Work, 79(3), 263-282.

Cigrang J. A., Peterson A. L, \& Schobitz, R. P. (2005). Three American troops in Iraq: Evaluation of a brief exposure therapy treatment. Pragmatic Case Studies in Psychotherapy, 1(2),1-2.

Council on Social Work Education. (2010). Advanced social work practice in military social work. Retrieved from http://www.cswe.org/File.aspx?id=42466

Cross, T., Bazron, B., Dennis, K., \& Isaacs, M. (1989). Towards a culturally competent system of care, Volume I. Washington, DC: Georgetown University Child Development Center, CASSP Technical Assistance Center. Retrieved from http://www.wavawnet.org/publicfiles/TheContinuumRevised.pdf

Daley, J. G. (1999). Social work practice in the military. Binghamton, NY: Haworth Press, Inc. 
Daley, J. G. (2003). Military social work: A multi-country comparison. International Social Work, 46(4), 437-448.

Dochy, F., Segers, M., Van den Bossche, P., \& Gijbels, D. (2003). Effects of problembased learning: A meta-analysis. Learning and Instruction, 13, 533-568.

Hartsell, B. D., \& Parker, A. J. (2008) Evaluation of problem-based learning as a method for teaching social work administration: A content analysis. Administration in Social Work, 32(3), 44-62.

Herzog, J., \& Everson, R. (2010). Secondary traumatic stress, deployment phase, and military families: Systematic approaches to treatment. In R. B. Everson \& C. R. Figley (Eds.), Families under fire: Systemic therapy with military families (pp.191212). New York: Routledge Psychological Stress Series.

Hosek, J. R., Kavanagh, J., \& Miller, L. (2006). How deployments affect service members. RAND Corporation. Retrieved from http://www.rand.org/pubs/monographs/2005/RAND_MG432.pdf

Hoge, C. W., Castro, C. A., Messer, S. C., McGurk, D., Cotting, D. I., \& Koffman, R. L. (2004). Combat duty in Iraq and Afghanistan, mental health problems, barriers to care. New England Journal of Medicine, 351(1), 13-22.

Huebner, A. J., Mancini, J. A., Bowen, G., \& Othner, D. (2009). Shadowed by war: Building community capacity to support military families. Family Relations, 58(2), 216-228.

Kadis, J., \& Walls, D. (2005). Military facts for non-military social workers. VHA Social Work Service Staffing and Clinical Practice Committee. Retrieved from: http://www.mhawisconsin.org/Uploads/veterans/military-facts-for-nonmilitarysocial-workers.pdf

Kam Pun Wong, D., \& Lam, D. (2007). Problem-based learning in social work: A study of student learning outcomes. Research on Social Work Practice, 17(1), 55-65.

Knox J., Pflanz, S, Talcott, G. W., Campise, R. C., Lavigne, J. E., Bajorska, A., Xin T., \& Caine, E. D. (2010). The US Air Force suicide prevention program: Implications for public health policy. American Journal of Public Health, 102(1), 613-621.

Knox, J., \& Price, D. H. (1999). Total force and the new American military family: Implications for social work practice. Families in Society, 80(2), 128-136.

Lam, D. (2009). Impact of problem-based learning on social work students: Growth and limits. British Journal of Social Work, 39(8), 1499-1517.

Litz, B. T. (2007). Research on the impact of military trauma: Current status and future directions. Military Psychology, 19(3), 218-238.

McFarlane, A. C. (2009). Military deployment: The impact on children and family adjustment and the need for care. Current Opinion in Psychiatry, 22(4), 369-373. 
Savery, J. R. (2006). Overview of problem-based learning: Definitions and distinctions. Interdisciplinary Journal of Problem-based Learning, 1(1), 3. Retrieved from: http://docs.lib.purdue.edu/ijpbl/vol1/iss1/3

Savitsky, L., Illingworth, M., \& DuLaney, M. (2009). Serving the military and veteran populations. Social Work, 54(4), 329-339.

Simmons, C. A., \& DeCoster, V. (2007). Military social workers at war: Their experiences and the educational content that helped them. Journal of Social Work Education, 43(3), 497-512.

Williamson, S., Chang, V., Fellows, M., \& Decker, C. (2007). Using modified problembased learning to teach social work practice skills. Presentation at the IUSSW FACET Retreat. Retrieved from http://www.facet.iupui.edu/pdf/Retreat/07_Modified_PBL_Social_Work_Williamson Chang.pdf

\section{Author's note:}

Address correspondence to: James D. Whitworth, Ph.D., University of West Florida School of Justice Studies and Social Work, 11000 University Parkway, Pensacola, FL 32514. Email: jwhitworth@uwf.edu 


\section{Appendix}

\section{Survey}

(For all questions below, the terms military member and veteran consist of any person who has served or is serving in the US Armed forces, which includes Active Duty, Retired, Separated, National Guard, and Reserve military members)

1. Have you ever been or are you currently a military member or a veteran? Yes

No

2. Have you ever been married to or had a partner relationship with a military member or veteran? Yes No

3. Have you had any work experience with a military member, veteran, or their family members? Yes _ No (if no skip to question 4)

Briefly describe the setting/location/role of your working with military members, veterans, or their families:

4. Please rate your level of knowledge of military populations prior to completing your military social work course (circle one)?
None
Very little
Moderate
Good
Extensive

5. Briefly describe your desired goals or outcomes for taking the military social work course:

6. Do you remember any of the military member, military family, or veteran case scenarios that were discussed in your military social work course? Yes__ No___ (if no skip to question 9)

7. Briefly describe one of the military member, military family, or veteran case scenarios that were discussed in your military social work course:

Please rate how helpful you believe these case scenarios were in helping you understand how to help military member, military family, or veterans?
Not Helpful
Somewhat Helpful
Helpful
Very Helpful

8. Are you currently working with or do you plan on working with military members, military families, or veterans? Yes No

9. For military and family members, the following are potential barriers for seeking social service assistance:

o concerns about confidentiality

o concerns about the impact of receiving care on the career of the service member

o All of the above

o None of the above

10. "Mission readiness" is the focus of which of the following military program(s)?

o $\quad$ Family Advocacy Program

o Substance Abuse Programs

o Medical Programs

o Mental Health Programs

o None of the above

11. Young Military families are an at risk population because of:

o No transportation

o Strained finances

o Limited coping skills

o Young age

o None of the above

12. Military members and their families face a number of unique demands and risks. These include:

0 Increased stress due to drawdowns

o Mission change

o A high number of young families with young children

o Separation from natural support networks 
Instructions for questions 14 - 23: We want to know how confident you are, in your ability to perform specific tasks with military members, their family members or veterans. After you consider each task below, please rate your confidence in your ability to perform that task successfully, by circling the number from 0 to 100 that best describes your level of confidence. What we mean here by successfully, is that you would be able to perform the specific task in a manner that a supervisor would consider excellent. The phrases above the numbers $[0=$ Cannot do at all; $50=$ Moderately certain can do; and $100=$ Certain can do] are only guides. You can use these numbers or any of the numbers in between to describe your level of confidence. We want to know how confident you are that you could successfully perform these tasks today.

\begin{tabular}{|c|c|c|c|c|c|c|c|c|c|c|c|}
\hline \multirow{2}{*}{$\begin{array}{l}\text { How confident are you that you can... } \\
\begin{array}{l}\text { 13. Review all aspects of the client's case } \\
\text { and history to determine benefit } \\
\text { eligibility. }\end{array}\end{array}$} & \multicolumn{3}{|c|}{$\begin{array}{l}\text { Cannot } \\
\text { Do at all }\end{array}$} & \multicolumn{4}{|c|}{$\begin{array}{c}\text { Moderately certain } \\
\text { can do }\end{array}$} & \multicolumn{4}{|c|}{$\begin{array}{r}\text { Certain } \\
\text { can do }\end{array}$} \\
\hline & 0 & 10 & 20 & 30 & 40 & 50 & 60 & 70 & 80 & 90 & 100 \\
\hline $\begin{array}{l}\text { 14. Identify barriers to obtaining services } \\
\text { and develop plans for overcoming } \\
\text { barriers. }\end{array}$ & 0 & 10 & 20 & 30 & 40 & 50 & 60 & 70 & 80 & 90 & 100 \\
\hline $\begin{array}{l}\text { 15. Establish rapport with clients from } \\
\text { different cultural backgrounds and } \\
\text { experiences. }\end{array}$ & 0 & 10 & 20 & 30 & 40 & 50 & 60 & 70 & 80 & 90 & 100 \\
\hline $\begin{array}{l}\text { 16. Understand the impact of substance } \\
\text { abuse on military members or } \\
\text { veterans. }\end{array}$ & 0 & 10 & 20 & 30 & 40 & 50 & 60 & 70 & 80 & 90 & 100 \\
\hline $\begin{array}{l}\text { 17. Critically evaluate substance abuse } \\
\text { issues with a military member or } \\
\text { veteran. }\end{array}$ & 0 & 10 & 20 & 30 & 40 & 50 & 60 & 70 & 80 & 90 & 100 \\
\hline $\begin{array}{l}\text { 18. Provide information about substance } \\
\text { abuse to military members or } \\
\text { veterans. }\end{array}$ & 0 & 10 & 20 & 30 & 40 & 50 & 60 & 70 & 80 & 90 & 100 \\
\hline $\begin{array}{l}\text { 19. Work with various systems to obtain } \\
\text { services for military members or } \\
\text { veterans. }\end{array}$ & 0 & 10 & 20 & 30 & 40 & 50 & 60 & 70 & 80 & 90 & 100 \\
\hline $\begin{array}{l}\text { 20. Advocate on behalf of military } \\
\text { member or veteran. }\end{array}$ & 0 & 10 & 20 & 30 & 40 & 50 & 60 & 70 & 80 & 90 & 100 \\
\hline $\begin{array}{l}\text { 21. Network with agencies to coordinate } \\
\text { services for military members or } \\
\text { veterans. }\end{array}$ & 0 & 10 & 20 & 30 & 40 & 50 & 60 & 70 & 80 & 90 & 100 \\
\hline $\begin{array}{l}\text { 22. Define military member or veterans' } \\
\text { problems in specific terms. }\end{array}$ & 0 & 10 & 20 & 30 & 40 & 50 & 60 & 70 & 80 & 90 & 100 \\
\hline
\end{tabular}

23. Please write below your feedback on your overall perceptions of the military social work course:

Some items adapted from the Social Work Self-Efficacy Scale, Holden, G., Meenaghan, T., Anastas, J., \& Metrey, G. (2002). 